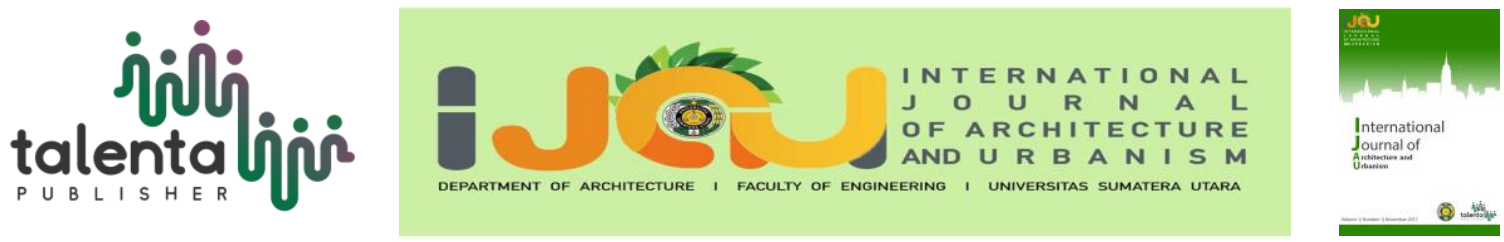

\title{
Traditional Market Design in Transit Oriented Development Area (TOD) in Pinang Baris
}

\author{
Achmad Delianur Nasution $^{1^{*}}$, Mega Ratu Pertiwi ${ }^{1}$ \\ ${ }^{1}$ Department of Architecture, Universitas Sumatera Utara, Medan, Indonesia
}

\begin{abstract}
According to the development plan of MEBIDANGRO, there are 21 modes of transportation in the future carried out repairs and revitalization, one of which is Pinang Baris Transit Oriented Development (TOD). The TOD Pinang Baris design integrates the Bus Terminal Pinang Baris with other building functions as a support, with sky bridge and pedestrian aimed at realizing a pedestrian-friendly and vehicle-free TOD region. One function of the building within the TOD Pinang Baris is the Traditional Market. Traditional Market is chosen to be a building that serves as a business center in the TOD area whose design is suitable for the behavior of users in the Market. Based on the analysis, The Traditional Market is designed on 2.5 hectares of land, with a building area of $16.802 \mathrm{~m} 2$, and the number of floors is 3 floors. General problems in the market such as hot, stuffy, smelly and wasteful use of electrical energy in traditional market solved by applying Green Architecture themes such as the design of skylights and voids providing natural lighting to conserve electricity and cross ventilation to keep it stuffy. Similarly, the inconvenience of building users in the market to the circulation that is difficult to access, then the design is applied circle circulation concept so that there are no more kiosks and loods that are isolated from the visitors. Therefore, thus, the implementation of green architectural themes in traditional markets can meet the needs and convenience of its user.
\end{abstract}

Keyword: traditional market, TOD, architecture, sustainable

\section{Introduction}

Many developed and developing countries that have successfully promoted the use of public transportation to move; the impact is the low number of private vehicles in the downtown so that traffic jam and pollution. In this case, Transit Oriented Development (TOD) offers a solution in the form of a regional concept in which it provides building functions as an activity generator that is integrated directly by the pedestrian to the building of the transit function.

No less important is the concept applied, the building functions as a supporter or container that accommodate various activities of this city must be right on target. The life of a Transit Oriented Development (TOD) becomes the determinant of the successful application of this concept. The economy is considered to be a magnet for people interested in activities in the

\footnotetext{
*Corresponding author at: Department of Architecture, Faculty of Engineering, Universitas Sumatera Utara,

Jalan Perpustakaan Gedung J07, Medan 20155, Indonesia

E-mail address: aan.nasution@gmail.com
} 
region. And in this case, the traditional market is one of the proper building functions to be designed within this Pinang Baris Transit Oriented Development (TOD) area. Traditional Market Design in the TOD area should be sensitive to the condition of the surrounding building function to realize the TOD area that successfully provides comfort to its users. Applying the concept is easy to access, designing TOD designs sky bridge and pedestrian that ensure pedestrians get good access to other building functions in the region. Therefore, the application of themes in traditional markets should be appropriate so that the identical problems of that such as heat, odor, mud, and stuffiness can be solved. The theme chosen to be applied to this Market is Green Architecture. This principle is a solution to problems in the market such as natural lighting, wind, air circulation, waste management and circulation that allows humans as users in it to overcome comfortable and suitable for users of Pinang Baris Traditional Market.

\section{Literature Review}

Transit Oriented Development (TOD) is an urban development approach that aims to address the number of private transportation usage, change the mindset of people to switch to the use of public transport and public facilities that can support pedestrians to explore the region [1]. Transit Oriented Development (TOD) is a mixed-use residential or commercial area intended to maximize access to public transportation. Such neighborhoods of consist of a center with a public station, surrounded by high-density development with gradually lower-density development spreading outward from the center [4].

Basically, this concept has transit points that not only serve as a place to serve passengers but as a place that provides various functions of the building where urban activities take place in the aspects of the economy, education, services and so forth. Traditional markets are a meeting place for sellers and buyers. In the market between the seller and the buyer will make the transaction. The exchange of goods and services between (individuals, companies and other organizations) other events that have economic influence over the business [3]. Terms of occurrence the transaction is there are traded; there are traders, there are buyers, there is a deal price of goods and no coercion from any party. Green architecture or design is an approach to minimizes harmful effects on human health and the environment. The "green" architect or designer attempts to safeguard air, water, and earth by choosing eco-friendly building materials and construction practices.

\section{Methodology}

The design begins with The Pinang Baris design in Transit Oriented Development (Figure 1), where the location is chosen because it sees the good potential of the land around Pinang Baris that Integrated with Terminal. Passive Terminal Integrated Pinang Baris became one of the focus of designing the application of the concept of Transit Oriented Development (TOD) to attract public interest to using public transportation modes and more walking to the 
building functions in there. The Traditional market as a business function that is believed to be the generator of the region to be visited and become a container that accommodates the activities of the economy.

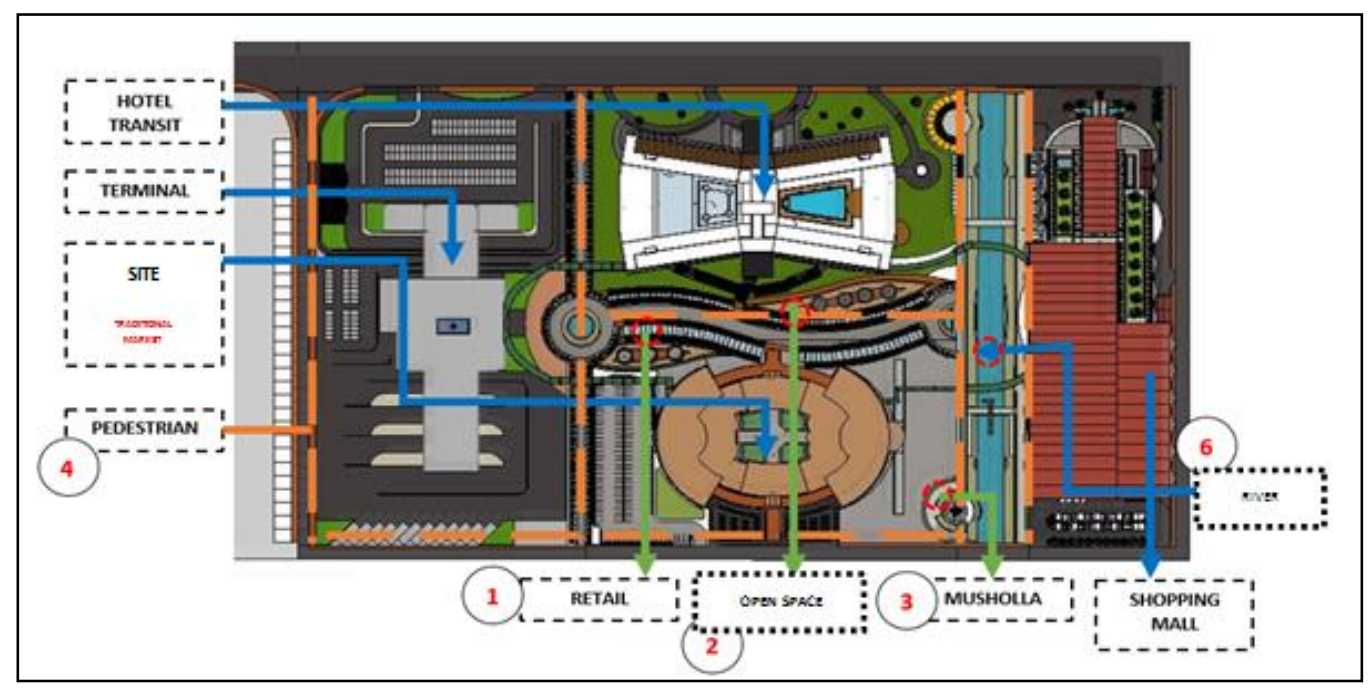

Figure 1. Master Plan

\section{Result and Discussion}

\subsection{Transit Oriented Development Area}

In the Transit Oriented Development Pinang Baris area, Terminal is a transit building function that became the center. Traditional Markets, Shopping Mall and Transit Hotel located in the area are functions that help move the region into a center of activity so that people are more encouraged to use public transportation in meeting their daily needs. Because the area you want to create must be walkable without a vehicle inside, then the integration between the terminal and other buildings should be able to provide comfort and security to its users. From this concept, then formed Master Plan TOD Pinang Baris where this design provides pedestrian for users as pedestrian and a bridge that connects one building and other or called Second Level so that visitors do not have to go down.

\subsection{The Green Architecture Theme Approach}

The design of Traditional Market Pinang Baris applying green architecture as the theme. Green architecture plays an important role in design. Building applications use the Green Architecture approach using the following features: Natural lighting applied to the design are the skylights and voids in the middle of the building. Skylight application aims to get the natural light of the sun into the building, which also serves as lighting in space (Figure 2). Following the concept of building mass is shaped like a symbol of Infinity which aims to provide unlimited circulation to the building. So, this also generalizes all loods and kiosks so visitors can access all segments of the building (Figure 3). 


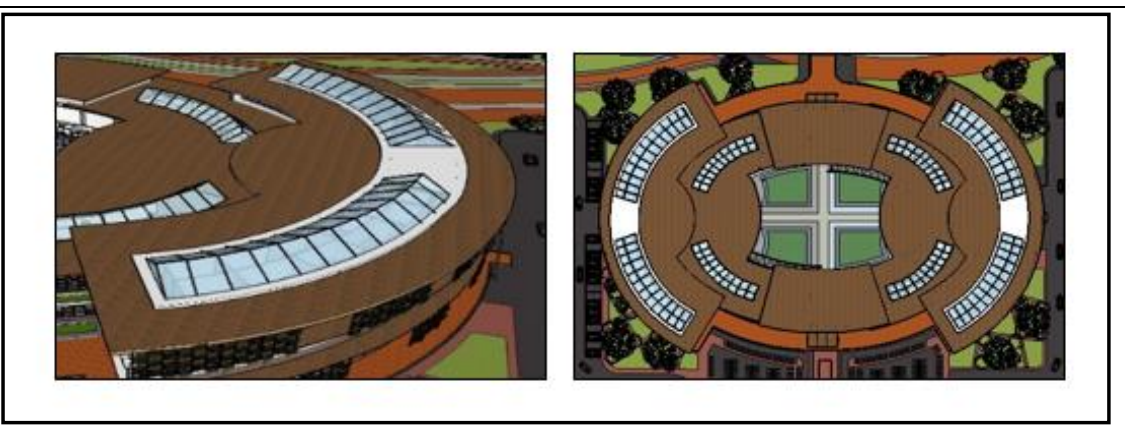

Figure 2. Natural Lightning

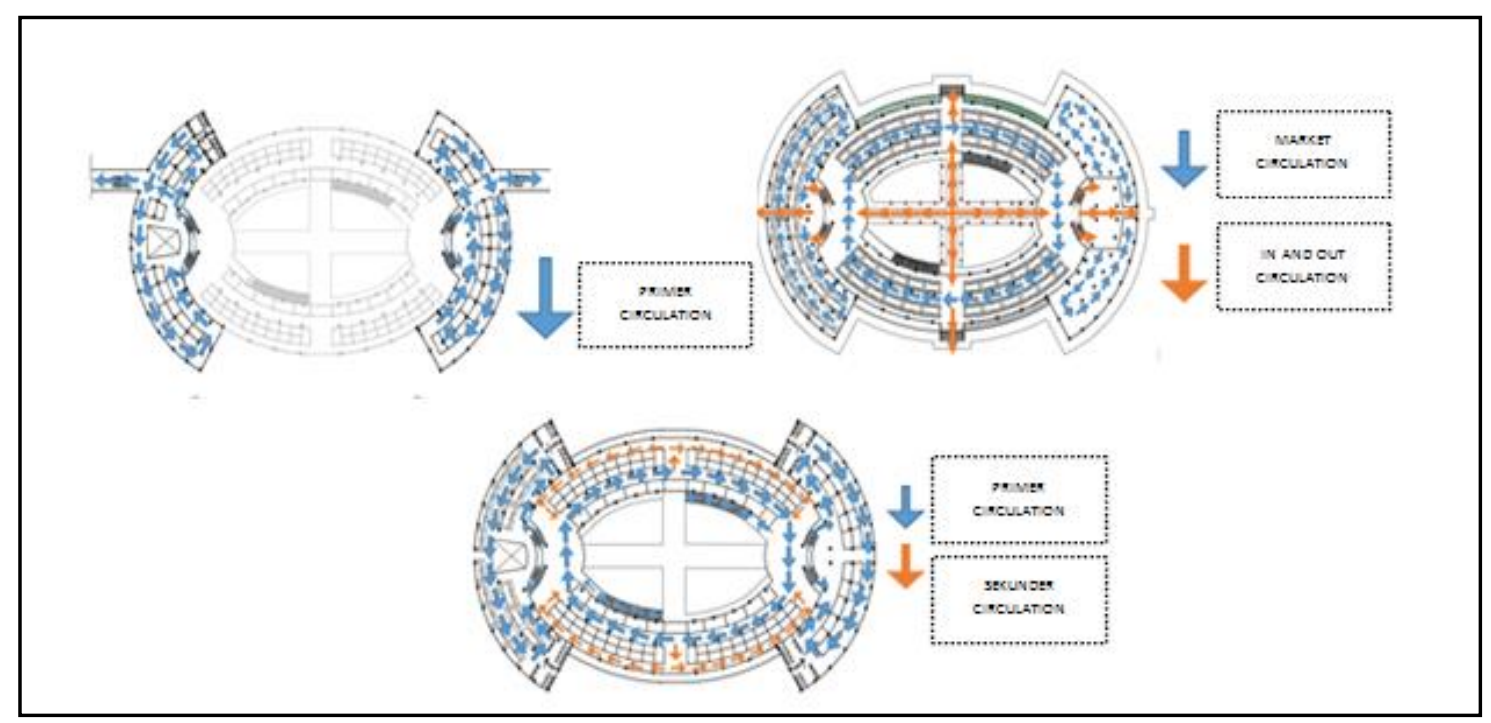

Figure 3. Circulation

Application of this concept provides openings for flowing air flow. Cross Ventilation from the front wall opening to the central void of the building. Likewise with the implementation of cross ventilation on the 2nd floor (Figure 4). The concept of Waste Management in buildings using WWTP (Wastewater Treatment Plant) where the dirty water is filter and re-process so that the water flowing to the city's riol is uncontaminated water (Figure 5).

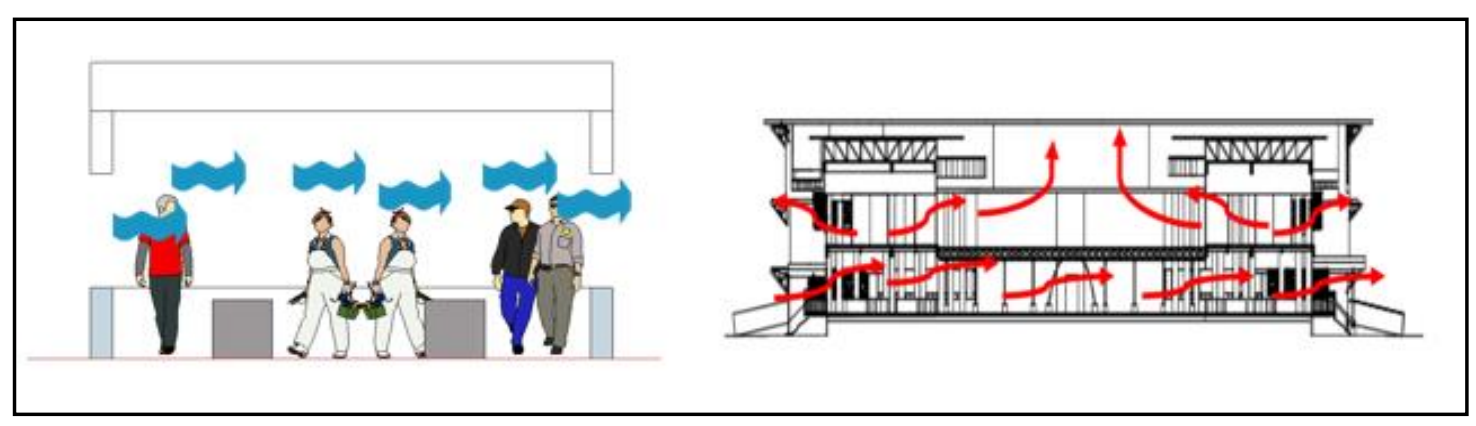

Figure 4. Circulation of Building 


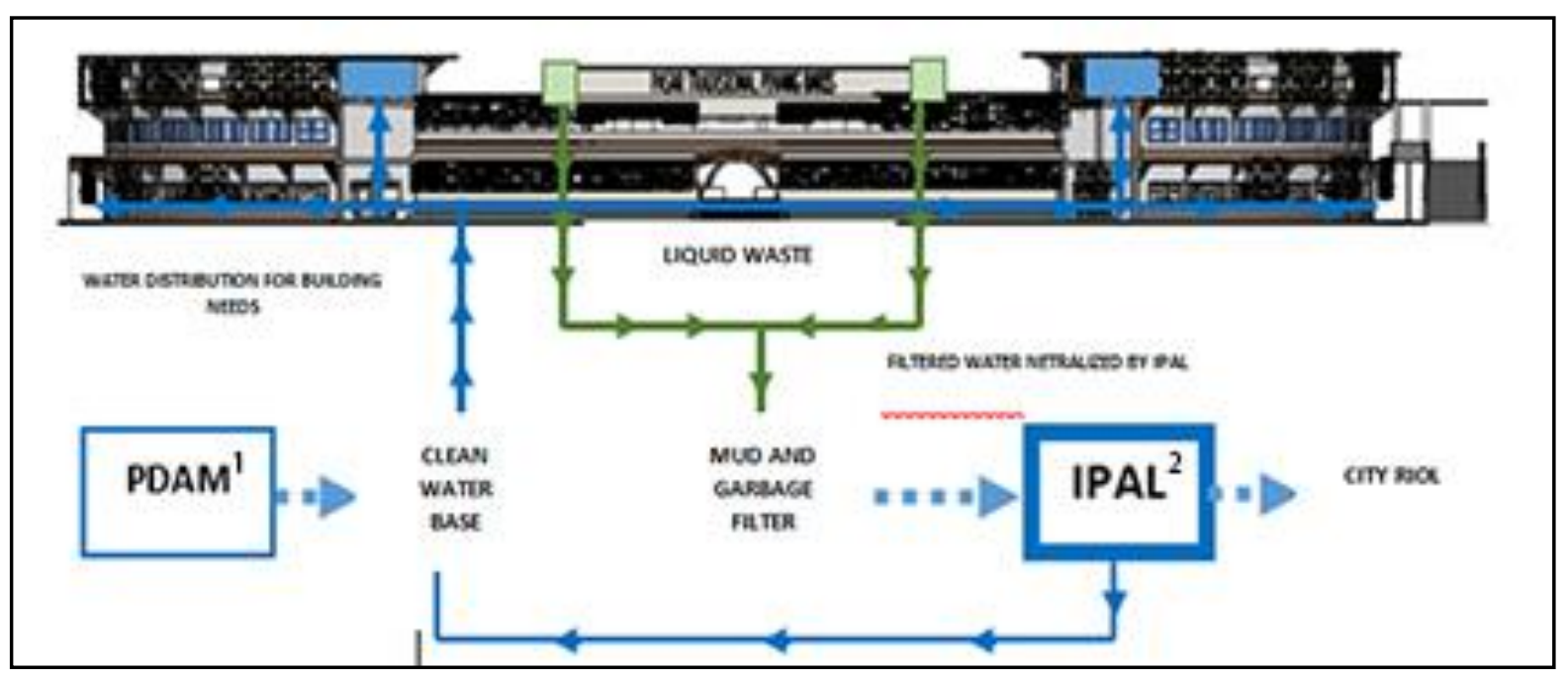

Figure 5. Waste of Management

*(Source: Author, 2017)

\subsection{Outdoor and Inside Spatial Planning}

The concept of tread design in the Traditional Market area in (TOD) area (Figure 6) prioritizes the quality for pedestrians from the Pinang Bus Terminal Bus to the market. So, the design of the external footprint in this market is pedestrian that integrates all the building functions in the area of Transit Oriented Development (TOD). In Pinang Baris Traditional Market design, there are zones that divide space and floor differences. These zones are designed to facilitate the users, there are sellers, employees, and visitors (Figure 7).

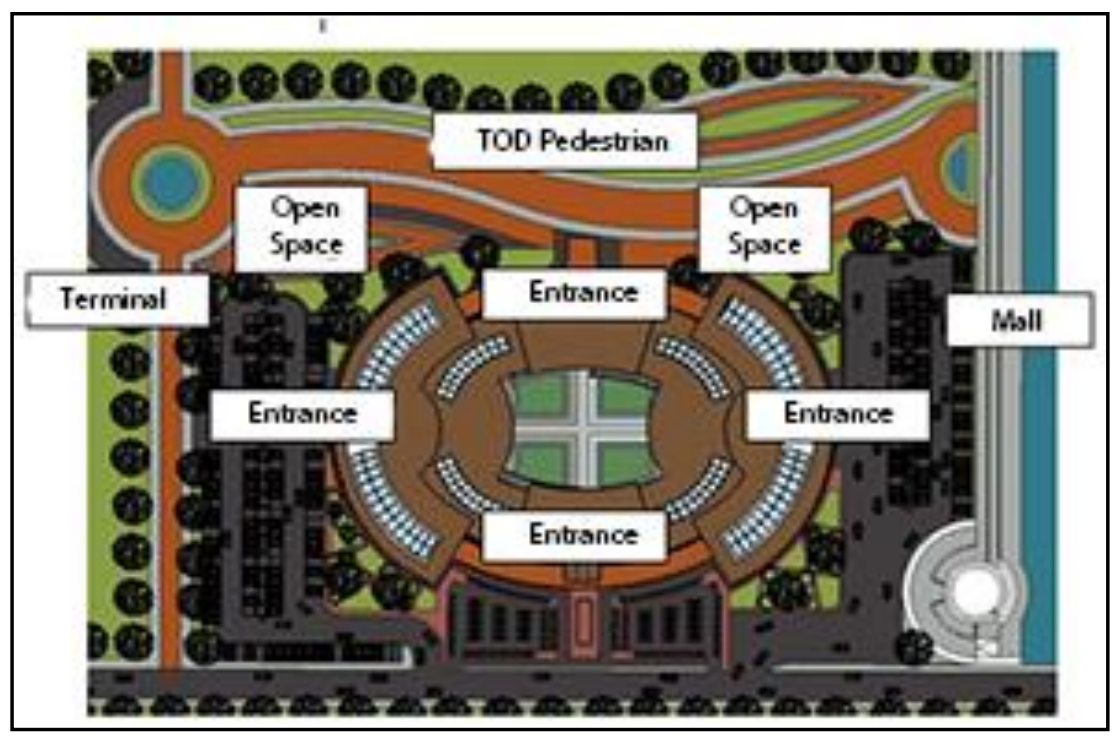

Figure 6. Outdoor Spatial Planning

\footnotetext{
* PDAM (Perusahaan Daerah Air Minum) : Local Water Company by Goverment

${ }^{2}$ IPAL (Instalasi Pengelolahan Air Limbah) : Waste Water Management Installation
} 


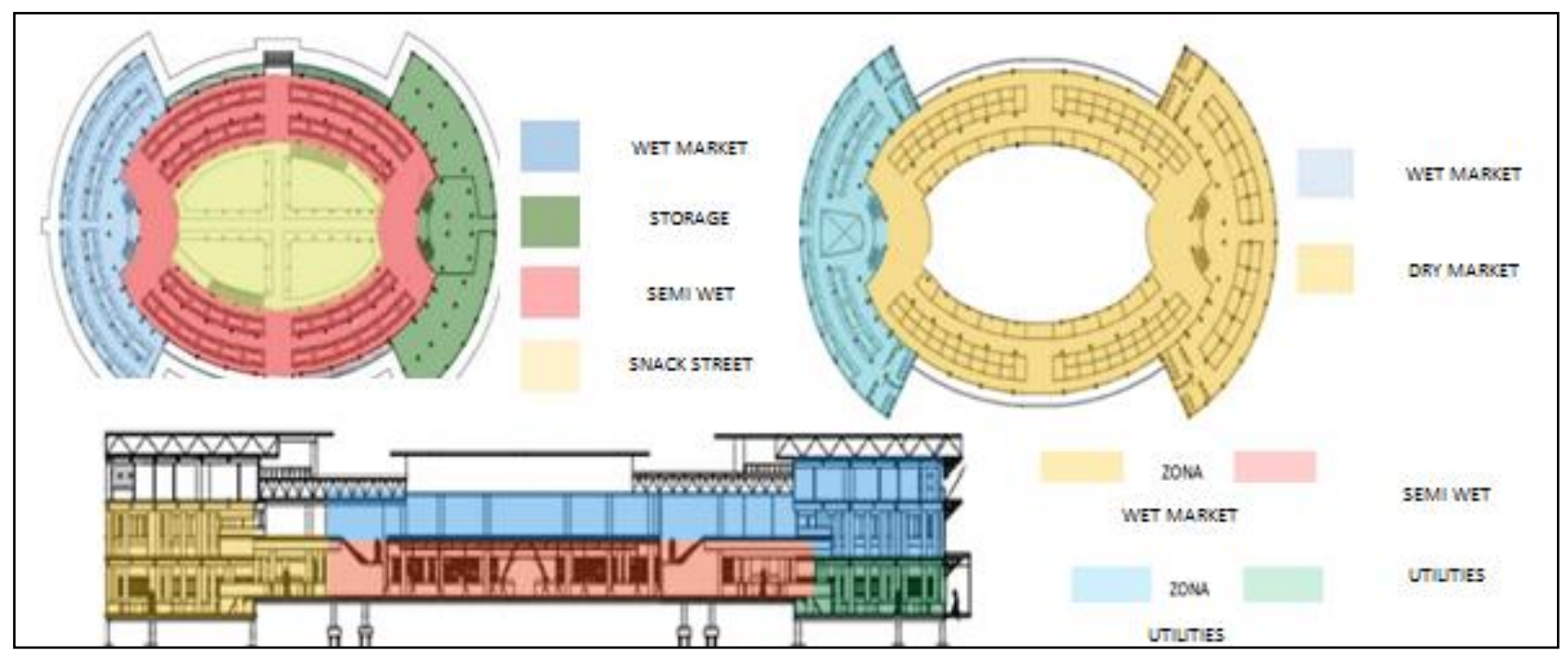

Figure 7. Zones

\subsection{Mass and Appearance}

Traditional markets typically use simple and accessible building materials. Likewise, with the design of this Traditional Market, the material is easy to get is one of the concepts of green architecture that applied to this building. Seen in the picture, the entire surface of the building facade looks transparent due to the large openings throughout the walls, and the facade elements become light barriers to keep the heat from entering the building (Figure 8).

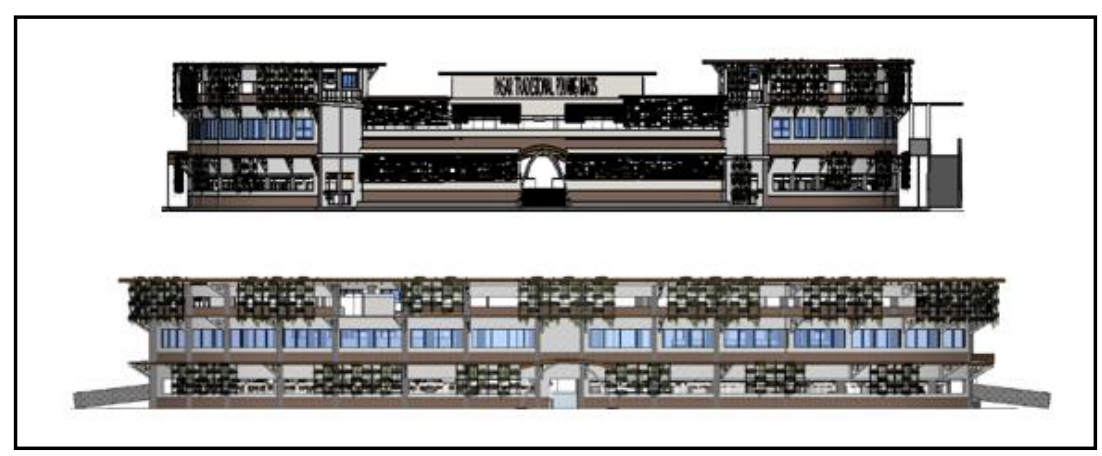

Figure 8. Mass and Appearance

\subsection{Structure and Construction System}

This building mass consists of two types of structures, there are a foundation and building structures. The foundation structure used pile foundation and reinforced with a structural system of columns and beams. In this building, using a 40/20 size beam while the smaller beam is $15 / 20$ and diameter column is $40 \mathrm{~cm}$.

\section{Conclusion}

According to the problems that have been discussed in the previous, The solutions implementation aimed to realize the building of Traditional Market becomes more comfortable to use, integrate well with Bus Terminal Pinang Baris, and able to apply green architecture as a theme which can solve these problem issues. 
A comfortable and humane market can be achieved by applying good quality circulation to its users. The circular formation is applied to form an unlimited circulation so there are no more kiosk and stall are isolated by visitors The design of the traditional Pinang Baris market in TOD area requires a nice integration between the market building with the TOD pedestrian, especially the Bus Terminal Pinang Baris that become activity generator in this area. In this case, Some efforts such as designing a multi-façade in the market building to respond to outside space into the building market. To provide comfort to pedestrians who are in TOD then in this area designing Level 2 bridges where pedestrians can move from one building to another without sun and rain. General problems in Traditional Market such as hot, stuffy, smelly, and wasteful in the use of electrical energy can be solved by the implementation of Green Architecture.

Therefore, the application of theme as skylights and voids to provide access to light and air flow in buildings. Secondary Skin has con wood material and creepers as a barrier to the sun's heat from the East and West. Then, the solution of market waste which is the source of the smell and muddy is given an IPAL implementation on building utility. WWTP can filter the market wastewater into the better water to be distributed to riol and recycled for reuse (reusable water). Therefore, the implementation of Green Architecture theme on Traditional Market can meet the needs and comfort of its user.

\section{Acknowledgment}

This research is part of the requirement to obtain a bachelor's degree in Architecture Department, Universitas Sumatera Utara.

\section{REFERENCES}

[1] P. Calthorpe. The next American metropolis: Ecology, community, and the American dream. Princeton architectural press. 1993.

[2] B. Vale; R. J. D. Vale; and R. DOIG, Ron. Green architecture: design for a sustainable future. Royal Victorian Institute for the Blind. Special Request Service, 1997.

[3] K. Skousen; J. Stice; \& E. Stice. Intermediate Accounting Thomson South-Western. 2007.

[4] J. Holmes; \& J. Van Hemert. Transit-oriented development. The Rocky Mountain Land Use Institute. 2008. 